www.czasopisma.marszalek.com.pl/pl/10-15804/npw

\author{
AleKSANDER ZBIRAŃSKI \\ Uniwersytet Marii Curie-Skłodowskiej \\ ORCID ID: https://orcid.org/0000-0002-1397-9356
}

\title{
Barbarzyńca ze Wschodu. Od stereotypu do mitologizacji Rosjan
}

\section{Barbarian from the East. From the stereotype to the mythologization of the Russians}

\section{Abstract}

The text presents the transformations of the image of Russia and Russians in Polish culture throughout history (from the eighteenth century to the present day). The aim of the article is to show ways to create stereotypes and national myths in order to achieve political goals. The political context of the changes taking place in the relations of Poles and Russians and its influence on shaping the image of the eastern neighbor is shown. The subject of creating stereotypes and national autostereotypes and the mythologization of one's own history was already discussed at the moment of current events of significant importance. The text shows the relationship between politics, identity and international relations in the context of the history and aspirations of independence of the Polish nation.

Keywords: Russia, Russians, culture, stereotypes, mythologization

\section{Варвар с востока. От стереотипа к мифологизации россиян}

\section{Аннотация}

В тексте представлены трансформации образа России и русских в польской культуре на протяжении истории (с восемнадцатого века до наших дней). Целью статьи является показать способы создания стереотипов и национальных мифов 
для достижения политических целей. Показан политический контекст изменений, происходящих в отношениях поляков и русских, и его влияние на формирование имиджа восточного соседа. Тема создания стереотипов и национальных автостереотипов и мифологизации собственной истории уже обсуждалась в момент актуальных событий, имеющих большое значение. В тексте показана связь между политикой, самобытностью и международными отношениями в контексте истории и стремления к независимости польской нации.

Ключевые слова: Россия, россияне, культура, стереотипы, мифологизация

$\mathrm{N}$ iniejszy artykuł przybliża sposób postrzegania Rosji i Rosjan przez Polaków na przestrzeni dziejów. Szczególną uwagę zwrócono na wykorzystanie stereotypów w ramach walk między narodami i w procesie mitologizacji tych starć w celu dowartościowania jednej ze stron. Prześledzenie ewolucji tych wyobrażeń umożliwia wskazanie ich „rdzenia”, który stanowi podstawę tworzenia kolejnych wizerunków wschodniego sąsiada i będących dostosowanymi do warunków danego czasu egzemplifikacjami tego podstawowego obrazu. Analiza antropologiczna pozwala wyodrębnić bazowe przekonania o przedmiocie stereotypu w celu lepszego zrozumienia funkcjonujących w zbiorowej wyobraźni przekonań na temat Rosji i Rosjan.

Stereotypy są jedną z form porządkowania doświadczenia zbiorowego. Zgodnie z definicją Waltera Lippmana jest to „obraz w głowie” przedstawiający dany przedmiot i określający jego cechy (Schaff, 1981, s. 37-40). Pozwala jednostce szybko zorientować się w rzeczywistości i określić swój stosunek wobec obiektu poznania. Stanowi swoisty „odgórny klucz interpretacyjny”, który ogranicza możliwości poznawcze i dostarcza gotowych sądów, które w owym uproszczonym obrazie są zawarte i gotowe „do użycia”. Tak istotny element otoczenia jakim jest Rosja w sposób naturalny staje się podstawą dla pojawiania się zarówno stereotypów, symboli, jak i mitów.

Wymienione wyżej sposoby porządkowania doświadczenia różnią się nacechowaniem aksjologicznym, złożonością treści i siłą oddziaływania na jednostkę. Mit jest prymarny spośród wszystkich tu wymienionych. Jest opowieścią objaśniającą świat i konstytuującą wspólnotę weń wierzącą (Czeremski, 2015, s. 24-28). Jest zarazem najbardziej złożony ze wszystkich trzech 
opisywanych zjawisk. Natomiast różnice pomiędzy stereotypem i symbolem zawierają się również $\mathrm{w}$ relacji pomiędzy przedmiotem a związaną $\mathrm{z}$ nim wartością. Jolanta Szymkowska-Bartyzel (2006, s. 14-16) przytacza poglądy Zbigniewa Benedyktowicza, który charakteryzował symbol jako znak będący nośnikiem wzniosłych treści (jako przykład podam Amerykę jako symbol wolności i równości obywateli) i niejako w opozycji prezentował stereotyp jako „spłaszczony” symbol. Ze względu na swój praktyczny charakter prezentuje obraz stanowiący parodię symbolu (chciwy Żyd, kochliwy Francuz lub flegmatyczny angielski gentelman). Można na tej podstawie sądzić, iż w symbolu znak (nawet jeśli jest realnie istniejącym obiektem) stanowi wyraz świata wartości przedstawiciela kultury, w której funkcjonuje. Stereotyp jest zaś przypisaniem wartości do konkretnego obiektu (narodu, grupy społecznej, państwa etc.). Zachodzą tu przeciwstawne procesy (w pierwszym wypadku od wartości do znaku, w drugim od znaku do wartości). Adam Schaff uważał, iż stereotyp ma przełożenie na praktykę życia, czyli postawy przyjmowane wobec przedmiotu stereotypu oraz podejmowanych wobec niego działań (Schaff, 1981, s. 118-120). To odniesienie do pragmatyzmu wskazuje, iż może on stanowić rodzaj wiedzy potocznej, która pozwala zrozumieć rzeczywistość i dzięki temu lepiej sobie radzić w jej ramach. Zgodnie z poglądami Williama Jamesa wiedza, która nie ma praktycznego zastosowanie nie jest prawdziwą wiedzą (James, 2016, s. 124). Jest to kompatybilne z potrzebami codziennego funkcjonowania w świecie. Szybkie sposoby oceniania ułatwiają sytuacje zetknięcia się z nowym lub nieznanym zjawiskiem. Jednostka wykorzystuje kulturowy zasób znaczeń przypisanych do konkretnego desygnatu. Oszczędza to czas potrzebny na rzeczywiste poznanie. Należy jednak zaznaczyć, iż jest to wzór postrzegania przedstawiciela danej grupy i nie można mylić go z archetypem jak czyni to Wojciech Cynarski (2005, s. 339-345). Archetyp jest wzorem do naśladowania w ramach danej kultury, będący wyrazem zbiorowej nieświadomości, pozwalający na tworzenie zrozumiałych tekstów kultury. Realizacja archetypu jest wpisanie się w określoną rolę „napisaną” przez kulturę. Stereotyp może przybliżyć się do niego, ale nie są to pojęcia tożsame. Ponadto zastrzeżenie budzi stwierdzenie, iż „wszystkie stereotypy są krzywdzące" (Cynarski, 2005, s. 341). Czy opinia, że wszyscy Cyganie pięknie grają na skrzypcach jest dla nich krzywdząca? Uproszczony model poznawczy może przypisywać zbiorowości zarówno cechy pozytywne (Niemcy są 
porządni i pracowici), jak i negatywne (cechuje ich buta i władczość). Wyróżnikiem stereotypu jest generalizacja niedopuszczająca wyjątków.

\section{Obraz Rosji i Rosjan wśród Polaków}

Stereotypy mogą być wykorzystywane w polityce oraz kreowane i renegocjowane zgodnie z jej bieżącymi potrzebami. Rosja jako odwieczny sąsiad Polski (również w okresie funkcjonowania jako Związek Radziecki) skupia na sobie uwagę Polaków jako istotny element otoczenia geopolitycznego ich kraju. Silne związki historyczne obu państw i kontakty kulturowe sprawiają, iż stereotypy wschodniego sąsiada nawet po pewnych zmianach wciąż są obecne. To właśnie owe zmiany (aktualizacje) świadczą o istotności zagadnienia i potrzebie posiadania stereotypu. Jego nosiciel może dzięki temu „wiedzieć” jacy są Rosjanie nigdy żadnego z nich nie spotykając. Ewolucja od „imperium barbarzyńców” do „Rosja to stan umysłu” ukazuje zmianę w relacjach między obydwoma państwami oraz zmiany kulturowe jakie zaszły w Polsce na przestrzeni dziejów. Sedno pozostaje jednak niezmienne. Prezentacja Rosji jako terytorium zacofanego cywilizacyjnie (znanego Polakom z zachodnich opinii o Polsce pod potoczną nazwą „białych misiów” na ulicach polskich miast) zmienia jedynie formy. W zmieniającym się kontekście społeczno-kulturowym niezbędne jest dostosowanie obrazu sąsiada do aktualnych potrzeb wspólnoty. Liczne wojny ze wschodnim sąsiadem zaowocowały w Polsce propagandowym obrazem Rosji jako państwa odstającego od europejskich norm i wartości, agresora zagrażającego ładowi kontynentu (Leinwald, 2013, s. 6). Jeszcze przed rozbiorami istniał w literaturze polskiej obraz Rosjanina nieznającego łaciny, wiarołomcy i grubianina niewolniczo uległego wobec cara. Państwo zaś jawiło się jako tyrania przeciwstawiona Rzeczypospolitej jako ostoi wolności i demokracji szlacheckiej. W okresie walk z Rosją o niepodległość kraju stereotyp barbarzyńskiego Rosjanina jest silnie eksploatowany. Podkreśla się agresywną naturę, brak moralności oraz odmienną wiarę. W czasie konfederacji barskiej chętnie atakowano również personalnie carycę Katarzynę II. Ponadto chętnie podnoszono argument, iż najpierw zaatakowana została Polska, później zagrożona będzie Europa. Polski mit przedmurza chrześcijaństwa jako istotny dla tożsamości narodowej został wykorzystany w sytuacji zagrożenia dla mobilizacji społecznej 
i będzie rewitalizowany jeszcze wielokrotnie (również w kolejnych konfliktach $\mathrm{z}$ Rosją). Atak na Polskę był równoznaczny z atakiem na chrześcijaństwo (Leinwald, 2013, s. 7-11).

W czasie insurekcji kościuszkowskiej w oficjalnych odezwach jej naczelnika pojawia się wątek podstępnych działań rosyjskich, niegodnych sposobów uprawiania polityki i instrumentalizacji religii. Kapłani greko-katoliccy zostają określeni jako niewolnicy caratu i są nakłaniani do przejścia na stronę Polski. W niepodległym państwie mają być „kapłanami szanowanymi”. Również w „rodzie rozbójników” (Leinwald, 2013, s. 12) Kościuszko upatruje sojuszników, którzy mogą opowiedzieć się za wolnością i przejść na stronę Polaków. Mimo dopuszczenia wyjątków, jednostek niepoddających się wadom narodowym, również w tym dyskursie można wskazać na generalizację opisującą wrogi naród jako jednorodną masę, z której należy się wyodrębnić by stanąć po stronie dobra. Widać tu kontynuację przeciwstawienia Polski (królestwa wolności i swobody, prawdziwej pobożności) oraz Rosji (tyranii wykorzystującej religię i duchownych do legitymizacji swoich zbrodni). W poezji insurekcyjnej opisywano naturę Rosjan jako ludzi chytrych, chciwych i srogich. Przypominano również wcześniejsze konflikty z Rosją. Umieszczenie aktualnych zdarzeń w kontekście politycznym pozwalało na ukazanie wroga jako wroga odwiecznego, zawsze stanowiącego niebezpieczeństwo dla Polski, nieustanne wyzwanie dla Polaków.

W XIX wieku, będącym okresem walk narodowowyzwoleńczych, była to narracja uzasadniająca dążenia niepodległościowe narodu znajdującego się pod zaborem rosyjskim. Za Polakami stały racje moralne i cywilizacyjne. Byli oni spadkobiercami dziedzictwa zachodniego chrześcijaństwa, którego bronili (również w późniejszych bojach) przed Moskalami. Jako przedstawiciele wyżej rozwiniętego kręgu kulturowego Polacy stawali się jego obrońcami („przedmurzem”), a przeciwstawieni im Rosjanie w konsekwencji byli postrzegani jako zagrożenie dla niego i jego osiągnięć. Ten dowartościowujący obraz zmieniał charakter wydarzeń z jednej z wielu walk między narodami o pewne terytorium i władzę nad nim w walkę o wartości. Jest to już przyczynek do mitologizacji owych zdarzeń i wpisanie ich w kosmiczny konflikt między siłami dobra i zła (Czeremski, 2015, s. 21-22). Myślenie mityczne jest widoczne w poezji powstania listopadowego, gdzie car jest ukazany jako główne źródło zła. Obalenie Mikołaja I ma sprawić, iż „w rodzinę jedną świat 
się zmieni” (Leinwald, 2013, s. 17). Pojawiają się również kolejne odwołania historyczne mające uargumentować bezprawny charakter działań cara, który nosi koronę z kradzionego złota. W typowy dla mitu sposób historia zmienia jest w naturę (Tomicki, 1987, s. 244-248) - przeszłość zlewa się w jeden ciąg zdarzeń świadczących o Rosji i Rosjanach, których zastępuje postać Moskala. Opisywane są jego cechy (zdradliwy, bezlitosny) oraz wymieniane winy jakie popełnił wobec Polaków. Likwiduje to walkę z jednostkowymi wrogami, gdyż tak naprawdę są jednym zbiorowym przeciwnikiem, którego należy pokonać w celu wyzwolenia narodu polskiego i przywrócenia porządku. Moskale są niejako emanacją okrutnego władcy, który zniewolił naród walczący o wolność. Jako ludzi na niższym poziomie cywilizacyjnym, niemal dzikich, cechowała ich agresja. Dawało to Polakom poczucie wyższości i legitymizowało ich działania przeciw niemal zwierzęcemu wrogowi.

Powstanie styczniowe pogłębia antagonistyczną wymowę polskiej narracji wobec Rosji. Wzmocniony został wątek rosyjskiego barbarzyństwa. Wprost wyrażone zostało przekonanie o konieczności dokonania wyboru między cywilizacją europejską a „dzikim barbarzyństwem Azji” (Leinwald, 2013, s. 20). Kwestia przynależności do Europy różnicowała państwa i narody. Państwa zaliczane do europejskich uznawane były za oświecone kraje wolności. Azjatów miała cechować agresja i niszczycielski charakter. Wschód (zarówno Bliski, jak i Daleki lub Ruś) był nacechowany negatywnie. Orient budził fascynację, ale jego mieszkańcy byli uważani za mniej inteligentnych, dzikszych, ulegających popędom (Wolniewicz, 2014, s. 104-108). Jako przykład można podać opis postaci Leonarda z Nie-Boskiej komedii. Akcja utworu rozgrywa się w Polsce, ale główny czarny charakter jest scharakteryzowany poprzez wschodnią aparycję (Janion, 2009, s. 150-154). Widoczny jest tu podział na centrum świata i jego peryferie. Do dnia dzisiejszego zresztą utrzymuje się waloryzacja świata zachodniego i wschodniego wedle powyższych standardów. Polska wpisując się w zachodnią cywilizację formułuje obietnicę lepszego świata, który nastąpi po jej wygranej. Opis cara jest podobny do wizerunku antychrysta - wymieniane są jego liczne zbrodnie, porównywany jest do biesów, oskarżany o plugawienie ołtarzy i rąbanie Krzyża Świętego (Leinwald, 2013 , s. 22). Jest to kolejny etap mitologizacji polskiej walki narodowowyzwoleńczej, która urasta do rangi naprawiania świata. Przy dodatkowym kontekście jakim był panujący w tym czasie mesjanizm można zauważyć 
wpisywanie przez Polaków swoich dziejów w historię obrony wiary i dzieła ratowania świata przed szatanem. W Kordianie ukazana jest scena, w której szatan odwodzi tytułowego bohatera od dzieła zabicia cara. Motyw cierpienia Polski jako Chrystusa Narodów jest też obecny w twórczości Mickiewicza. Polak w swej literaturze narodowej zmaga się z siłami zła utożsamianymi przez Rosję oraz ulegającymi personifikacji pod postacią Cara (wcześniej tę funkcję pełniła caryca Katarzyna). Warto też zaznaczyć, iż Polacy nigdy nie walczyli wyłącznie za siebie, ale również za innych. Obecnie do rangi autostereotypu urasta hasło Lelewela „za wolność waszą i naszą”. Ponadto Polacy symbolizowali nie tylko wolność, ale również wiarę katolicką (lub prawdziwe chrześcijaństwo) zagrożoną przez najeźdźców.

Stereotyp barbarzyńcy ze wschodu odżył wraz z rosnącym zagrożeniem ze strony Związku Radzieckiego, który utożsamiany był z mocarstwowymi dążeniami i azjatycką naturą Rosjan jako dzikiej hordy. Była to aktualizacja znanego kulturowego scenariusza eksponującego okrucieństwo i niszczący charakter wschodniego sąsiada stanowiącego zagrożenie dla Polski. W polskich plakatach propagandowych jest przedstawiany jako potwór, człowiek z cechami zwierzęcia, niekiedy bliżej mu do zwierząt niż ludzi. Eksponuje się wielkie zęby, krew, zarost, groźne spojrzenie. Bolszewików wprost określa się jako dzicz. Artur Oppman pisał o „barbarzyńskich hordach Wschodu”, natomiast Irzykowski opisywał stosunek polskich żołnierzy do bolszewików, którzy są dla nich „gorszym gatunkiem człowieka” (Szczotka, 2012, s. 207-208). Te zbliżające się do rasizmu elementy kreacji wizerunku wroga są powrotem do starych stereotypów o barbarzyńcach. W czasie wojny polsko-bolszewickiej owy pogląd był wyrażany w sposób dosłowny. Były również bardziej fantastyczne przedstawienia, w których bolszewicy przypominali trupy lub śmierć dosiadała konia o głowach Lenina i Trockiego. Motywy bolszewika-potwora i bolszewika-diabła można spotkać na wielu plakatach propagandowych oraz w niektórych tekstach lirycznych okresu omawianej wojny. Była to próba dehumanizacji wroga, stworzenia złudzenia, iż Polsce nie zagrażają ludzie, ale diabły i monstra, które należy pokonać. Łatwiej było wpisać oponenta w historię walki dobra i zła, zwłaszcza przy pomocy tekstów informujących o zagrożeniu dla Kościoła katolickiego oraz obsadzających Polaków w roli obrońców wiary i rewitalizujących mit przedmurza chrześcijaństwa. Za przykład można podać ukazanie postaci Piłsudskiego 
w stylistyce hagiograficznej typowej dla świętego Jerzego. Zdaniem biskupów wyrażonym w liście pasterskim bolszewicy szczególnie nienawidzili chrześcijaństwa, gdyż byli natchnieni przez antychrysta. Niszcząc Kościół mieli zniszczyć „wszelką kulturę”, co ukazuje, iż przypisywano ich do dzikiego świata przyrody, opisywano jako „zezwierzęconych czerwonych żołdaków” (Szczotka, 2012, s. 210-211). Ponadto ta narracja jest bezpośrednim wpisaniem ówczesnych wydarzeń w porządek religijny. „Propaganda polska niezależnie od formy przekazu przedstawiała te same treści [...] wrogowi przypisywano najgorsze cechy: okrucieństwo, despotyzm, brak szacunku dla wiary katolickiej, związki z diabłem. Bolszewika wyobrażano jako Azjatę, barbarzyńcę, kogoś gorszego od Europejczyka, niekiedy utożsamiano go z Żydem" (Szczotka, 2012, s. 213). W wojennej potrzebie posługiwano się stereotypami - istniejącymi już w kulturze obrazami grup uznawanych za gorsze i dowolnie je łączono ze stereotypem Rosjanina jako zagrażającego Polsce, a przez to również Europie.

W niektórych przekazach łączono obraz bolszewika ze stereotypem żydowskiego spisku skierowanego przeciw Polsce. Eksponowano pochodzenie Lwa Trockiego oraz innych przywódców rewolucji w Rosji. Fakty te wyolbrzymiano i wysnuwano $\mathrm{z}$ nich daleko idące wnioski o żydowskim charakterze rewolucji październikowej. Przykłady z prasy tamtego okresu przytaczane przez Pawła Śpiewaka ukazują, iż walka z bolszewizmem była naprawdę walką z „żydostwem”, któremu (jak każdemu wrogowi chrześcijaństwa) Polska stała na drodze do zapanowania nad światem (Śpiewak, 2012, s. 23). Jest to kolejny przykład wroga, który udowadnia dziejowe posłannictwo i wiekopomną misję przyświecające Polsce jako Chrystusowi Narodów i przedmurzu chrześcijaństwa. Naród zostaje wyniesiony do rangi naśladowców Jezusa i strażników jego spuścizny. Skojarzenie Rosjan (wiarołomców i barbarzyńców) z Żydami (podstępnymi bogobójcami) wydaje się naturalne. $Z$ dwóch wrogów uczyniono jednego (w celu uniknięcia rozproszenia uwagi) i wpisano w znany schemat. W stereotypowym ujęciu jedni i drudzy są zaprzeczeniem cywilizacji (utożsamianej z religią chrześcijańską) i dążą do jej upadku (poprzez zniszczenie Kościoła). Chrześcijaństwo jako wyznacznik stopnia ucywilizowania było stosowane wobec wszystkich grup etnicznych, które wielokrotnie otrzymywały miano „dzikich” (Wolniewicz, 2014, s. 104).W ten sposób łączono dwa stereotypy tworząc zunifikowanego 
przeciwnika. Warto jednak za Pawłem Śpiewakiem zaznaczyć, iż element żydowski w narracji łatwo zyskiwał dominantę, gdyż Żydzi mieli pełnić rolę kierowniczą i wysługiwać się „hordami” Rosjan i Azjatów. Było to rozwinięcie i ugruntowanie powstałego kilkanaście lat wcześniej mitu żydokomuny, który łączył „obcość” Żyda i komunizmu (Śpiewak, 2012, s. 22). Idee lewicowe były od XIX wieku łączone ze środowiskiem żydowskim, więc za powstanie państwa komunistycznego nie mógł odpowiadać nikt inny. Rosjanin był narzędziem w ręku żydowskim. W prasie endeckiej Rosjanie bywali też przedstawiani jako ofiara żydowskich „panów”, którzy stosowali wobec nich okrucieństwo (np. zdzieranie skóry). Zarzuty o ,judeobolszewizm” doprowadziły między innymi do internowania siedemnastu tysięcy żołnierzy Wojska Polskiego pochodzenia żydowskiego (Śpiewak, 2012, s. 23-24). Wynika z tego obraz Rosjanina jako naiwnego i łatwowiernego wykonawcy żydowskich rozkazów. W niektórych przekazach jest też żądnym krwi barbarzyńcom nieświadomym faktu, że jest narzędziem w odwiecznym planie przejęcia władzy nad światem przez Żydów.

W okresie dominacji Związku Radzieckiego w Europie Środkowo-Wschodniej oraz w czasach żelaznej kurtyny istniały dwa rozbieżne obrazy tego państwa. Jednym z nich był propagandowy wizerunek państwa wyzwolicieli Europy spod hitlerowskiego jarzma. Przeciwstawny był obraz rozprzestrzeniony na Zachodzie, który można streścić pod hasłem „imperium zła”. Sposób myślenia o Rosji i Rosjanach zawsze był uwikłany w konteksty polityczne. Oba kreowane obrazy Związku Radzieckiego były efektem propagandy mającej wzbudzić określone emocje u odbiorców. W obecnej rzeczywistości Polska nie jest w stanie konfliktu zbrojnego ani bezpośrednio zagrożona atakiem ze strony wschodniego sąsiada. Jednak mit wroga czyhającego na Polaków odżył w momencie katastrofy smoleńskiej. Powstawały liczne teorie spiskowe przypisujące winę Rosjanom, którzy mieli przeprowadzić zamach i uśmiercić w ten sposób Prezydenta Rzeczypospolitej Polskiej. Dawne stereotypy dotyczące mocarstwowych aspiracji Rosji, agresywnego i podstępnego sposobu prowadzenia polityki oraz stanowienia zagrożenia dla Polski odżywają w momentach negatywnie ocenianych poczynań rosyjskich władz. Manewry wojskowe w pobliżu polskich granic, aneksja Krymu, nieprzychylne Polsce wypowiedzi rosyjskich polityków powodują powrót starych obrazów obecnych w polskim imaginarium kulturowym. 
Analogie między rzekomym zamachem w Smoleńsku oraz zbrodnią katyńską wpisują się w opisywany wcześniej ciąg długich reminiscencji krzywd doznawanych od wschodniego sąsiada. Podobny charakter mają odniesienia do zdradzieckiej natury Rosjan i „noża wbitego w plecy” Polski 17 września 1939 roku. Należy jednak zaznaczyć, iż nie tylko Polacy w ten sposób postrzegali Rosjan. Podstępny charakter przypisywali im również Niemcy rozciągając go na wszystkich Słowian (Dmitrów, 1997, s. 291-316). Podobne opinie utwierdzone autorytetem korespondentów można było przeczytać w dawnej prasie brytyjskiej (Sakowicz-Tebinka, 2010, s. 239-242).

\section{Nowe wyobrażenia Rosji}

W codziennym życiu, wolnym od politycznych napięć, funkcjonuje nowy typ ikonicznych reprezentacji Rosji. „Rosja to nie kraj, to stan umysłu” jest hasłem występującym w Internecie i zapowiadającym niezwykłe zachowanie Rosjan uwiecznione na zdjęciu lub video. Te teksty kultury w sposób humorystyczny znów odwołują się do różnić kulturowych i stanowią maksymalnie złagodzone współczesne wcielenie „barbarzyńskiej hordy”. Obcość cywilizacyjna i rasowa (Wolniewicz, 2014, s. 192-199) została zastąpiona przez obcość kulturową i mentalną mieszkańców Rosji w stosunku do Zachodu, którego Polska obecnie jest częścią. Służy to umocnieniu poczucia zachodnioeuropejskiej tożsamości Polaków oraz podkreśla różnicę między nimi a Rosjanami. Od wieków odmawiano Rosji europejskości, statusu państwa cywilizowanego. Te internetowe komunikaty wizualne są tylko egzemplifikacją istniejącego przekonania o nieprzystawaniu Rosji do Europy i Zachodu. Sprawiają również, iż Rosja jest nieustannie obecna w polskiej wyobraźni jako potencjalny wróg. Pozwalają one wyodrębnić wspomniany na początku „rdzeń” wszystkich analizowanych wyobrażeń na temat Rosji i Rosjan. Wszystkie dziwne sytuacje ukazywane na zdjęciach (pralka zawieszona na drzewie - rzekomo jako karmnik dla ptaków lub ogrodzenie placu zabaw zwieńczone drutem kolczastym) mają udowadniać „obcość” kultury narodu rosyjskiego w stosunku do Europejczyków. Oskarżenia o barbarzyństwo (posiadania innych zwyczajów, których nie da się pogodzić z „naszą” kulturą stanowiącą punkt odniesienia) stanowią podstawę do generowania kolejnych stereotypów i warunkują poczucie wyższości odbiorców w stosunku do 
sąsiadów ze wschodu. Dodatkowym efektem jest dowartościowanie kultury polskiej, która przy porównaniu z rosyjską jawi się jako „prawdziwie europejska”. Polacy stają się przedstawicielami wyżej rozwiniętej cywilizacji przeciwstawionej zacofanej i dzikiej Rosji (szczególnie wymowne są zdjęcia z niedźwiedziami traktowanymi jak zwierzęta domowe).

Każde nietypowe zachowanie udokumentowane w formie nagrania video lub fotografii jest potwierdzeniem wcześniej założonej tezy (Lippmanowskiego „obrazu w głowie”) i pojedynczy przykład ulega generalizacji na całą nację. Dodatkowe podkreślanie, iż „Rosja to nie kraj, to stan umysłu” wskazuje na dostrzegane przez twórców tych komunikatów różnice w mentalności pomiędzy narodami. Jest to ukonkretnienie pojęcia „obcości kulturowej” Rosjan - innego sposobu myślenia, postrzegania rzeczywistości i stylu życia. Nie jest to jedynie kwestia organizacji struktur państwowych i formy sprawowania rządów, władz świeckich lub sytuacji geopolitycznej. Ich inność jest cechą przyrodzoną, która jest właściwa wszystkim przedstawicielom narodu. W czasach pokoju (choć zdarzają się również konflikty dyplomatyczne) między Polską a Rosją jest to sposób na podtrzymanie stereotypu w obiegu i utwierdzania swoje tożsamości jako przedstawiciela ostatniego europejskiego (kulturowo) państwa na wschodzie. Zachowanie stereotypów służy zabezpieczeniu możliwości szybkiego rozeznania się jednostki w sytuacji konfrontacji z ich przedmiotem.

\section{Podsumowanie}

Posiadanie wroga jest potrzebne każdemu narodowi w celu zachowania wewnętrznej jedności i samookreślenia jako członka wspólnoty zewnętrznie zagrożonej przez niecnego wroga, który zawsze posiada pewne cechy: inność - utożsamiana z zagrożeniem, brzydota, smród, niższość rozumiana wedle aktualnych kryteriów społeczno-kulturowych (Eco, 2012, s. 9-24). Warto dodać, iż miano „barbarzyńcy” często odnoszone do Rosjan zakłada nie tylko pewien sposób zachowania, ale również upośledzenie umysłowe (Eco, 2012, s. 13). Na tle wroga grupa uznająca się za „tą właściwą” może dowartościować się i wyznaczać sobie wyznacznik (będący jednocześnie dla nich potwierdzeniem) wyznawanych przez nią wartości. Zagrożenie ze strony Rosji (mniej lub bardziej rzeczywiste) jest Polsce potrzebne do 
tworzenia własnej tożsamości oraz utwierdzania swojego autostereotypu obrońców wartości, których w możliwościach rozwoju ogranicza jedynie nieszczęśliwe położenie geograficzne. Określanie swojego położenia poprzez odniesienie do rosyjskiej agresji ma w kulturze polskiej wciąż istotną pozycję. Olga Lipińska zdiagnozowała to w swoim kabarecie i wyraziła w postaci wielokroć powtarzanego cytatu (stworzonego przez nią, stylistycznie naśladując XIX-wieczną literaturę): ,idźcie przez zboże, we wsi Moskal stoi”. Moskal jest elementem polskiej mitologii narodowej, w której Polak reprezentuje siły dobra (Chrystus Narodów) w odwiecznej walce dobra ze złem reprezentowanym przez wschodniego barbarzyńcę mającego związki z nieucywilizowaną Azją i od czasu rewolucji październikowej inspirowanego przez diabła.

\section{MGR ALEKSANDER ZBIRAŃSKI}

Uniwersytet Marii Curie-Skłodowskiej

ul. Misjonarska 24/8, 20-107 Lublin

Alek_zbir@interia.eu

\section{Bibliografia}

Cynarski, W. (2005). Kulturowy archetyp i etos a postrzeganie charakteru narodowego. W: A. Andrusiewicz (red.). Polska i jej wschodni sasiedzi, T. 5 (339-350). Rzeszów: Wydawnictwo Uniwersytetu Rzeszowskiego.

Czeremski, M. (2015). Problemy z mitologizacja kultury. W: W. Charchalis, B. Trocha (red.). Mitologizacja kultury w polskiej i iberyjskiej twórczości artystycznej (21-32). Zielona Góra: Uniwersytet Zielonogórski.

Dmitrów, E. (1997). Obraz Rosji i Rosjan w propagandzie narodowych socjalistów 1933 1945. Warszawa: Instytut Studiów Politycznych PAN.

Eco, U. (2012). Wymyślanie wrogów i inne teksty okolicznościowe. Poznań: Rebis. Janion, M. (2009). Bohater, spisek, śmierć. Wykłady żydowskie. Warszawa: WAB.

Leinwald, A. (2013). Rosja w propagandzie polskich powstań narodowych 1768-1864. Wybrane zagadnienia.Studia z Dziejów Rosji i Europy Środkowo-Wschodniej, XLVIII, 5-25.

Sakowicz-Tebinka, I. (2010). Imperium Barbarzyńców. Rosja Aleksandra II w brytyjskich opiniach prasowych. Gdańsk: Wydawnictwo Uniwersytetu Gdańskiego.

Schaff, A. (1981). Stereotypy a działanie ludzkie. Warszawa: Książka i Wiedza.

Szczotka, S. (2012). Wizerunek bolszewika w polskich plakatach propagandowych z wojny polsko-rosyjskiej 1919-1920 ze zbiorów Muzeum Niepodległości w Warszawie. Niepodległość i Pamięć, 19/1-4 (37-40), 205-213. 
Szymkowska-Bartyzel, J. (2006). Amerykański mit polski konsument czyli reklamowe oblicza Ameryki. Kraków: Wydawnictwo Uniwersytetu Jagiellońskiego.

Śpiewak, P. (2012). Żydokomuna. Interpretacje historyczne. Warszawa: Czerwone i Czarne. Tomicki, R. (1987). Mit. W: Z. Staszczak (red.). Słownik etnologiczny. Terminy ogólne (244-248). Warszawa-Poznań: PWN.

Wolniewicz, M. (2014). Moskwa ante portas. Rosja w polskiej propagandzie powstańczej (1863-1864). Poznań: Wydawnictwo Nauka i Innowacje. 
